\title{
Stimulation of salmon calcitonin on secretion of $17 \beta$-estradiol by the ovarian follicles of common carp, Cyprinus carpio
}

\author{
Sudipta Paul, Dola Mukherjee, Kousik Pramanick, Sourav Kundu, S P Bhattacharyya, Priyanka De ${ }^{1}$ \\ and Dilip Mukherjee \\ Endocrinology Laboratory, Department of Zoology, University of Kalyani, Kalyani 741235, West Bengal, India \\ ${ }^{1}$ Molecular Endocrinology Laboratory, Indian Institute of Chemical Biology, 4, Raja SC Mullick Road, Kolkata 700032, India \\ (Correspondence should be addressed to D Mukherjee; Email: dilipmukher@rediffmail.com)
}

\begin{abstract}
The effects of salmon calcitonin $(\mathrm{sCT})$ on the secretion of $17 \beta$-estradiol $\left(\mathrm{E}_{2}\right)$ were examined in female common carp, Cyprinus carpio. Vitellogenic stage fish adapted to high-Ca water were i.p. injected with vehicle, sCT, human chorionic gonadotropin (hCG), or hCG plus sCT. To determine whether ovarian follicles are equipped with CT receptors, a CT binding assay was conducted. In the in vitro experiments, vitellogenic follicles were incubated with stimulators and inhibitors. Administration of $\mathrm{sCT}$ increased the basal and hCG-stimulated $\mathrm{E}_{2}$ release in vivo and in vitro. Binding characteristics of $\left[{ }^{125} \mathrm{I}\right] \mathrm{sCT}$ to plasma membrane preparation of carp ovarian follicles showed saturability with high-affinity $\left(K_{\mathrm{d}}=48.48 \mathrm{pmol} / 1\right.$ and $B_{\max }=1.2 \mathrm{pmol} / \mathrm{mg}$ protein $)$. To clarify the mechanism of $\mathrm{E}_{2}$ production by $\mathrm{sCT}$, in vitro effect of $\mathrm{sCT}$ and hCG on aromatase activity (conversion of testosterone to $\mathrm{E}_{2}$ ) and cytochrome $\mathrm{P} 450$ aromatase
\end{abstract}

(P450arom) gene expression in carp ovarian follicles were investigated. Salmon CT-stimulated both aromatase activity and P450arom gene expression in ovarian follicles of carp. sCT-stimulated $\mathrm{E}_{2}$ release by the ovarian follicles in vitro was augmented in the presence of dibutyryl cAMP. Inhibitor of protein kinase A (PKA), SQ 22536 inhibited sCT-stimulated steroid production in a dose-dependent manner. Specific inhibitor of protein kinase C (PKC), NPC-15437 dihydrochloride had no inhibitory effects on sCT-induced $\mathrm{E}_{2}$ release. The present study indicates that $\mathrm{sCT}$ binds specifically to carp ovary and stimulates $\mathrm{E}_{2}$ production by increasing the activity of cytochrome P450 aromatase and P450arom gene expression. The results further suggest that stimulatory action of $\mathrm{SCT}$ on $\mathrm{E}_{2}$ production is mediated through cAMP pathway. Journal of Endocrinology (2008) 196, 413-424

\section{Introduction}

Calcitonin (CT), a 32-amino acid peptide, is synthesized by the C cells of mammalian thyroid gland (Copp et al. 1962, Foster et al. 1964) and ultimobranchial gland of nonmammalian vertebrates (Copp et al. 1967). The classic concept of CT function in mammals has focused on its effects on calcium homeostasis (Azria 1989). By comparison, the role of CT on calcium homeostasis in fish has long been controversial. Conflicting results concerning hypocalcemic effect of CT have been reported, depending on the species and protocol followed (Chan et al. 1968, Yamauchi et al. 1978, Wendelaar Bonga \& Pang 1991). This situation changed completely when gills were recognized as one of the many target organs for CT action in fish (Milhaud et al. 1977). Some recent information indicated that $\mathrm{CT}$ exerts its hypocalcemic action in fish through inhibition of gill calcium transport (Wagner et al. 1997, Mukherjee et al. 2004a). We also demonstrated that as in mammals, hypocalcemic effect of CT in certain teleost is exerted through bone calcium resorption (Mukherjee et al. 2004b).
In addition to the involvement of $\mathrm{CT}$ in calcium homeostasis, its action on brain, pituitary, and gonad have been investigated in mammals. Specific CT-binding sites have been found in the brain and pituitary gland (Fischer et al. 1981, Maurer et al. 1983) and in the ovary and testis (Chausmer et al. 1982, George et al. 1997). In addition to the thyroid, CT-like immunoreactivity has been found in the pituitary gland of humans and rats (Cooper et al. 1980). Wang et al. (1994) found that CT-like peptide including human CT, $\mathrm{sCT}$, and CT gene-related peptide, inhibit the spontaneous and gonadotropin-stimulated testosterone secretion by acting directly at the testes and reducing the release of pituitary luteinizing hormone ( $\mathrm{LH})$. Inhibition of $\mathrm{SCT}$ on secretion of progesterone and gonadotrophin-releasing hormone $(\mathrm{GnRH})$-stimulated release of pituitary LH hormone in rats has also been documented (Tsai et al. 1999). Reports are available that plasma CT exhibited a peak concentration on the day of diestrus and reduced to the lowest on the day of estrus (Cressent et al. 1983). All these observations indicate an endocrine role of endogenous $\mathrm{CT}$ at the brain, pituitary, and gonad in mammals. 
From the beginning of the study on the effects of CT in fish, its action on the regulation of reproduction has been proposed by many workers. Evidence is available on high plasma CT levels during peak spawning season in Coho salmon, Japanese eel, and rainbow trout (Deftos et al. 1974, Yamauchi et al. 1978, Bjorsson et al. 1986). Increase in plasma $\mathrm{CT}$ level by the induction of $\mathrm{E}_{2}$ has been reported in Coho salmon (Bjorsson et al. 1989). Available information suggests that $\mathrm{CT}$ is involved in mobilizing calcium or in directing its mobilization by protection of a certain calcium pool during vitellogenesis (Bjorsson et al. 1989). Suzuki et al. (2004) described that $\mathrm{E}_{2}$ acts on UBG to induce the release of CT, which in turn may play an important role in reproduction directly and or indirectly through calcium. Although these studies indicate a relationship between CT and fish reproduction they fail to explain the exact link between them. However, no effort has yet been made in fish to study the effect of CT, if any, at the ovarian level directly or at the brain-pituitary levels to modulate the reproduction indirectly.

The present study makes an attempt to examine the effects of sCT on the basal and hCG-stimulated in vivo release and in vitro production of $\mathrm{E}_{2}$ by ovarian follicles of Cyprinus carpio. To determine whether fish ovarian follicles are equipped with functional CT receptors, a CT-binding assay was conducted. Cytochrome P450arom is the key enzyme for conversion of testosterone to $\mathrm{E}_{2}$ in the granulosa cells. The P450arom mRNA levels are increased in association with increases of enzyme activity during vitellogenesis in teleost (Fukada et al. 1996, Kagawa et al. 2003). Therefore, the aim of the present study was to elucidate the role of sCT on aromatase activity and P450arom gene expression in the ovarian follicles of common carp. Furthermore, we have carried out experiments which show that signal transduction of the stimulatory effects of sCT on $\mathrm{E}_{2}$ release by the ovarian follicles may be operated through cAMP pathway.

\section{Materials and Methods}

\section{Animals}

Adult female common carp C. carpio (300-400 g body wt), collected from a local fish farm during the months of September and October were maintained in recirculating dechlorinated normal tap water in laboratory concrete tanks (300 1 capacity, $\mathrm{Ca}^{2+}, 0 \cdot 15 \mathrm{mM}$ ) at $23 \pm 2{ }^{\circ} \mathrm{C}$ for 5 days. They were fed with commercial fish food (Shalimar Fish Food; Bird and Fish food manufacturer, Mumbai, India). Fish were then transferred to high-calcium water (number of fish $=120$, $\mathrm{Ca}^{2+}, 0 \cdot 4 \mathrm{mM}$ ) for 7 days before treatment.

During the months of September and October in the plains of West Bengal, India, the ovary offemale common carp comprises mostly of vitellogenic follicles $(0 \cdot 3-0 \cdot 4 \mathrm{~mm}$ diameter) with oocytes containing centrally located germinal vesicle. The cytoplasm was filled with yolk granules and cortical granules were shown to cover the entire oocyte. Follicular developmental stage was determined by stripping out a few follicles through the ovipore followed by examination under microscope after fixing them with a clearing solution of acetic acid-ethanol-formalin mixture $(1: 6: 3 \mathrm{v} / \mathrm{v})$ for $12 \mathrm{~h}$.

\section{Chemicals}

Synthetic sCT, (Lot no. 118H49611), all cold steroids, and dibutyryl cyclicAMP (dbcAMP) were purchased from Sigma Chemicals. Human chorionic gonadotropin (hCG) was a gift from National Hormone and Pituitary Program (Torrance, CA, USA). SQ 22536 (RBI, Natick, MA, USA) and NPC-15437 dihydrochloride (Sigma) were gifts from Dr Arun Bandopadhyay, Molecular Endocrinology Laboratory, Indian Institute of Chemical Biology, Kolkata. Tricanemethane sulfonate (MS 222) was a gift from Sandoz Basels, Switzerland. Total RNA isolation (TRI) reagent was purchased from Ambion Inc., Foster City, CA, USA. Smart-PCR cDNA synthesis kit was purchased from Clontech. RevertAid M-MuLV reverse transcriptase and deoxyNTPs were procured from MBI Fermentas and Taq DNA polymerase from Invitrogen. Labeled steroids, $\left[{ }^{3} \mathrm{H}\right]$ estradiol-17 $\beta$ (sp. activity $75 \cdot 0 \mathrm{Ci} / \mathrm{mmol}$ ), $\left[{ }^{3} \mathrm{H}\right]$ testosterone (sp. activity $95 \cdot 0 \mathrm{Ci} / \mathrm{mmol}$ ), and $\left[{ }^{125} \mathrm{I}\right] \mathrm{sCT}$ (Code IM250, sp. activity $2000 \mathrm{Ci} / \mathrm{mmol}$ ) were procured from Amersham Biosciences. The $\mathrm{E}_{2}$ antibody was a gift from Prof. Gordon Niswender, Colorado State University, Fort Collins, CO, USA. All other chemicals used were of analytical and molecular biology grade.

\section{Effects of sCT on plasma $E_{2}$ levels}

Vitellogenic stage fish, after being maintained for 7 days in high-Ca ${ }^{2+}$ water, were given i.p. a single injection of increasing concentration of $\mathrm{SCT}$ in such a way that each fish received $0 \cdot 1,0 \cdot 5,1 \cdot 0$, or $2 \cdot 0 \mu \mathrm{g} \mathrm{sCT} / 100 \mathrm{~g}$ body wt. Controls were injected with vehicle $(0 \cdot 6 \%$ aqueous saline and $1 \%$ gelatin preparation). Sampling of fish was done $8 \mathrm{~h}$ after injection. In another experiment, a group of fish was given single injections of sCT $(0.5 \mu \mathrm{g} / 100 \mathrm{~g}$ body wt) or hCG $(0.5 \mu \mathrm{g} / 100 \mathrm{~g}$ body wt) or hCG plus sCT (each $0.5 \mu \mathrm{g} / 100 \mathrm{~g}$ body wt) at $0700 \mathrm{~h}$ in the morning. Controls were injected with vehicle. Fish were sampled at $0,2,4,8,12,16$, and $24 \mathrm{~h}$ after injection. The volume of vehicle in both the experiments was $20 \mu \mathrm{l}$ per fish. Fish were lightly anesthetized with MS $222(1: 1000, \mathrm{pH} 7 \cdot 4)$ before injection. Immediately after sampling, blood was collected from the caudal vein under light anesthesia, processed for plasma separation, and kept at $-20^{\circ} \mathrm{C}$ until steroid analysis.

\section{In vitro incubation of ovarian follicles}

The donor fish (vitellogenic stage) selected for ovarian follicles were killed by decapitation at $0700 \mathrm{~h}$ in the morning and ovaries were placed in ice-cold Idler's medium containing streptomycin $(100 \mu \mathrm{g} / \mathrm{ml})$ and penicillin $(100 \mathrm{IU} / \mathrm{ml})$ adjusted to $\mathrm{pH} 7 \cdot 4$ (Mukherjee et al. 2006). Follicles, after 
collection were kept separately in ice-cold medium until use. $\sim 100 \mathrm{mg}$ follicles were initially placed in individual wells of a 24-well culture plate (Tarson, Kolkata, India) for $2 \mathrm{~h}$ that contained $1.0 \mathrm{ml}$ control medium. This $2-\mathrm{h}$ pre-incubation time was required to waive the surgical shock (Mukherjee et al. 2006). After $2 \mathrm{~h}$, the medium was replaced with fresh medium containing stimulators and inhibitors. Inhibitors were added $1 \mathrm{~h}$ prior to the addition of test compounds. Cultures were placed in a metabolic shaker bath at $23 \pm 1{ }^{\circ} \mathrm{C}$ under air. Viability of ovarian follicles was observed to be about $90 \%$ as detected using $0 \cdot 1 \%$ Trypan blue dye exclusion. At the end of incubation, medium samples were aspirated, centrifuged $(5000 \mathrm{~g})$, and stored at $-20^{\circ} \mathrm{C}$ for $\mathrm{E}_{2}$ measurement by specific RIA. Aromatase activity in the ovarian follicles in response to $\mathrm{SCT}$ and $\mathrm{hCG}$ was estimated by in vitro conversion of labeled testosterone to labeled $\mathrm{E}_{2}$ using the method of Chan \& Tan (1986). For this, ovarian follicles $(100 \mathrm{mg})$ were incubated in the absence or presence of sCT $(50 \mathrm{ng} / \mathrm{ml})$ or hCG $(50 \mathrm{ng} / \mathrm{ml})$ for $12 \mathrm{~h}$ at $23 \pm 1{ }^{\circ} \mathrm{C}$. All incubations contained $140 \mathrm{pmol}^{3}[\mathrm{H}]$ testosterone $\left(1 \times 10^{6}\right.$ c.p.m., sp. activity $\left.5400 \mathrm{mCi} / \mathrm{mmol}\right)$.

\section{$R N A$ isolation and $c D N A$ preparation}

Total RNA was extracted from isolated ovarian follicles (in both control and treated groups) using TRI Reagent solution following the manufacturer's instruction and the method described earlier (Chomczynski \& Sacchi 1987) and cDNA was synthesized using Smart-PCR cDNA synthesis kit following the manufacturer's instruction.

\section{RT-PCR}

First-strand cDNA synthesis was carried out with $2 \mu \mathrm{g}$ total RNA using RevertAid M-MuLV reverse transcriptase. To the tube oligo $(\mathrm{dT})_{18}$ primer, reverse transcription reaction buffer, RNAase inhibitor, deoxyNTPs were mixed (final volume $20 \mu \mathrm{l}$ ) and incubated at $42{ }^{\circ} \mathrm{C}$ for $1 \mathrm{~h}$ for first-strand cDNA synthesis. From the cDNA prepared, $2 \mu \mathrm{l}$ were used as template for RT-PCR with gene-specific primer, and relative expression was observed with glyceraldehyde-3-phosphate dehydrogenase (GAPDH) primer (Roy et al. 2003). A $50 \mu \mathrm{l}$ PCR volume was made by adding $2 \cdot 5 \mathrm{U}$ Taq DNA polymerase to a PCR mixture containing $1 \times$ reaction buffer $(50 \mathrm{mM} \mathrm{KCl}, 10 \mathrm{mM}$ Tris- $\mathrm{HCl}$ (pH 8.3), 0.1\% Triton-X-100, and $\left.2.5 \mathrm{mM} \mathrm{MgCl}_{2}\right), 200 \mu \mathrm{M}$ of each deoxyNTPs and $20 \mathrm{pmol}$ of each primer. The PCR was performed for 35 cycles of denaturation at $94{ }^{\circ} \mathrm{C}$ for $30 \mathrm{~s}$ (5 min in the first cycle), annealing at specific temperature for each set of primers for $30 \mathrm{~s}$, and extension at $72^{\circ} \mathrm{C}$ for $30 \mathrm{~s}$ (10 min in the last cycle; Applied Biosystems, Foster City, CA, USA). The RT-PCR products were cloned, sequenced, and used for the expression purpose. The primers (used for RT-PCR) of the respective genes with the accession number and their amplified segments are listed in Table 1.

\section{Membrane preparation of ovarian follicles for sCT binding assay}

Membrane was prepared from ovarian follicle using the method of Birnbaumer \& Swartz (1982) with few modifications. To state briefly, ovarian follicles after isolation were washed three to four times with chilled Idler's medium, weighed and homogenized in sodium phosphate buffer $(0 \cdot 01 \mathrm{~mol} / \mathrm{l}, \mathrm{pH} 7 \cdot 4)$ under ice for $30 \mathrm{~s}$. The homogenate was passed through single layer cheesecloth to remove fat and cell debris and then spun at $3000 \mathrm{~g}$ in a refrigerated centrifuge for $10 \mathrm{~min}$. The $3000 \mathrm{~g}$ pellet was re-centrifuged at $20000 \mathrm{~g}$ for $30 \mathrm{~min}$ at $4{ }^{\circ} \mathrm{C}$. After washing, the pellet was re-suspended in phosphate buffer $(0.01 \mathrm{~mol} / 1, \mathrm{pH} 7 \cdot 4)$ in the ratio of $1 \mathrm{~g} / 10 \mathrm{ml}$ and stored at $-70{ }^{\circ} \mathrm{C}$ until use. Protein content of the preparation was measured according to the methods of Lowry et al. (1951) using BSA as the standard.

\section{sCT binding assay}

The incubation medium used for binding assays contained $5 \mathrm{mM} \mathrm{MgCl}_{2} / 1,0 \cdot 1 \mathrm{~mol}$ sucrose $/ 1$, and $0 \cdot 1 \%(\mathrm{w} / \mathrm{v}) \mathrm{BSA}$ in phosphate buffer $(0 \cdot 01 \mathrm{~mol} / 1, \mathrm{pH} 7 \cdot 4)$. For $\left[{ }^{125} \mathrm{I}\right] \mathrm{sCT}$ binding, membrane preparation $(2 \cdot 0 \mathrm{mg}$ protein) was incubated with $20 \mu \mathrm{l}\left[{ }^{125} \mathrm{I}\right] \mathrm{sCT}$ solution $\left(\sim 1 \times 10^{5}\right.$ c.p.m.) in the absence (total binding) or presence of a 1000-fold excess of unlabeled sCT to measure nonspecific binding. Final assay volume was $500 \mu \mathrm{l}$ at $23{ }^{\circ} \mathrm{C}$. Incubation was terminated at $90 \mathrm{~min}$ by addition of bovine $\gamma$-globulin $(0 \cdot 1 \% \mathrm{v} / \mathrm{v})$ and $\mathrm{NaCl}(0 \cdot 1 \mathrm{~mol} / \mathrm{l})$. Ice-cold polyethylene glycol (PEG; $1 \mathrm{ml}, 20 \% \mathrm{w} / \mathrm{v}$ ) was then added

Table 1 Primers used in semi-quantitative RT-PCR

Forward primer

\section{Gene product \\ CYP19A (cytochrome P450 aromatase; DQ534411) \\ GAPDH (AJ870982)}

5' TACACATTCTGGAGAGTTTTTATCA 3'

5' AGGGGCTCAGTATGTTGTGG 3'
Reverse primer

\author{
Size of \\ amplicon (bp)
}

5' GGAAGTTGTCTAGACTGAACTCAT 3' 198

5’ AGGAGGCATTGCTGACAACT 3' 185 
to each tube under ice. The contents of these tubes after vortex were centrifuged at $1500 \mathrm{~g}$ for $10 \mathrm{~min}$ in a refrigerated centrifuge followed by aspiration of the supernatant. Pellets were then rinsed twice with $1.0 \mathrm{ml}$ chilled assay buffer and centrifuged. The final pellets were counted in a $\left[{ }^{125} \mathrm{I}\right] \gamma$ counter. Specific binding was estimated by subtracting nonspecific binding from total binding.

\section{Extraction and assay of steroids}

The method of extraction of $\mathrm{E}_{2}$ from plasma and incubation medium was similar to the previously described procedure for this steroid (Mukherjee et al. 2001, Sen et al. 2002). Anti- $E_{2}$ serum was highly specific and cross-reacted with $E_{2}$, testosterone, $17 \alpha$-hydroxyprogesterone, and cortisol at 100, 1 , $<0 \cdot 01,<0 \cdot 01$, and $<0 \cdot 01$ respectively. The sensitivity of the assay was $12 \mathrm{pg} / \mathrm{ml}$. Intra-assay and inter-assay coefficient of variation were 9 and $12 \%$ respectively.

\section{Statistical analysis}

All data were expressed as means \pm s.E.M. Data from each experiment were subjected to one-way ANOVA followed by Bonferroni's multiple comparison tests. The level of significance chosen was $P<0 \cdot 05$.

\section{Results}

Plasma calcium and $17 \beta$-estradiol $\left(E_{2}\right)$ levels in response to $s C T$ and $h C G$

Results shown in Fig. 1A demonstrate that $\mathrm{SCT}$ in increasing doses $(0 \cdot 1,0 \cdot 2,0 \cdot 5,1 \cdot 0$, or $2 \cdot 0 \mu \mathrm{g} / 100 \mathrm{~g}$ body wt) caused a gradual rise in plasma $E_{2}$ levels in carp $8 \mathrm{~h}$ after injection. The maximum effective dose was $0.5 \mu \mathrm{g}$. The minimum dose at which sCT was able to induce an increase in plasma $\mathrm{E}_{2}$ levels was $0 \cdot 1 \mu \mathrm{g}$.

Intraperitonial injection of vehicle did not alter the levels of plasma $\mathrm{E}_{2}$ in carp (Fig. 1B). After $2 \mathrm{~h}$ of $\mathrm{sCT}$ injection $(0.5 \mu \mathrm{g} / 100 \mathrm{~g}$ body $\mathrm{wt})$, the mean concentration of plasma $\mathrm{E}_{2}$ increased by $22 \%$ and a maximum $(77 \cdot 92 \%)$ was recorded at $8 \mathrm{~h}$ followed by a gradual decline leading to basal plasma value at $24 \mathrm{~h}$. Injection of hCG- $(0.5 \mu \mathrm{g} / 100 \mathrm{~g}$ body wt $)$ stimulated $\mathrm{E}_{2}$ release and the highest plasma $\mathrm{E}_{2}$ concentration was recorded at $12 \mathrm{~h}$ (Fig. 1B). Injection of hCG plus sCT (each $0.5 \mu \mathrm{g} / 100 \mathrm{~g}$ body wt) resulted in a significantly higher level of plasma $\mathrm{E}_{2}$ at $8 \mathrm{~h}$ and $12 \mathrm{~h}$ after challenge when compared with that induced by hCG alone $(P<0 \cdot 05$, Fig. $1 \mathrm{~B})$.

Mean levels of total and ultrafiltrable plasma calcium in vitellogenic stage fish at all time points were $3.8 \pm 0.4 \mathrm{mM}$ and $1.6 \pm 0.17 \mathrm{mM}$, respectively, for the vehicle-injected group, $3.75 \pm 0.34 \mathrm{mM}$ and $1.6 \pm 0.15 \mathrm{mM}$, respectively, for the hCG-injected group, and $3 \cdot 85 \pm 0.36 \mathrm{mM}$ and $1 \cdot 65 \pm 0.17 \mathrm{mM}$, respectively, for the sCT-injected group.
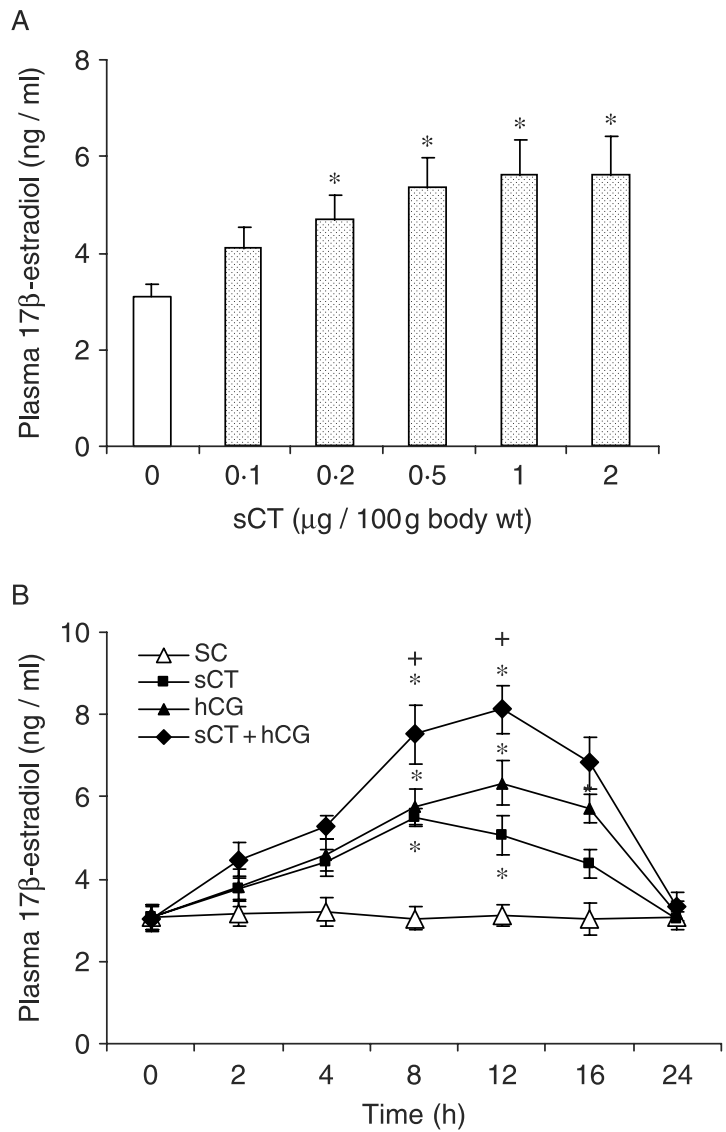

Figure 1 Dose-response effects of (A) salmon calcitonin (sCT) and a time-course study on the effects of (B) sCT $(0.5 \mu \mathrm{g} / 100 \mathrm{~g}$ body wt), human chorionic gonadotropin (hCG, $0.5 \mu \mathrm{g} / 100 \mathrm{~g}$ body wt), and hCG + sCT (each $0.5 \mu \mathrm{g} / 100 \mathrm{~g}$ body wt) on plasma concentration of $17 \beta$-estradiol $\left(E_{2}\right)$ in vitellogenic stage C. carpio. (A) Fish were injected with increasing doses of sCT as indicated and killed $8 \mathrm{~h}$ after injection. (B) Fish were given a single i.p. injection of sCT, hCG or sCT+hCG. Blood samples were collected from caudal vein at time indicated after hormone challenge. Each value $(A$ and $B)$ is mean \pm s.E.M. of five observations (SC, saline control, (A) $* P<0.05$ versus $\mathrm{SCT}$ at $0 \mu \mathrm{g} / 100 \mathrm{~g}$ body wt, (B) ${ }^{+} P<0.05$ versus hCG at $0.5 \mu \mathrm{g} / 100 \mathrm{~g}$ body wt).

No significant differences in plasma calcium levels were observed among these three groups.

\section{sCT binding to fish ovarian tissue}

Membrane preparation $(2 \cdot 0 \mathrm{mg}$ protein) from fish ovarian follicles was subjected to incubation with $\left[{ }^{125} \mathrm{I}\right] \mathrm{sCT}$ where radiolabeled $\mathrm{SCT}$ was added in increasing concentrations $(0 \cdot 5-4 \cdot 0 \mathrm{nM})$. Figure $2 \mathrm{~A}$ shows that with increasing concentrations of $\left[{ }^{125} \mathrm{I}\right] \mathrm{sCT}$, the specific binding increases until $2 \mathrm{nM}$ and then saturation was reached. Scatchard plot analysis of the data (Fig. 2B) showed that $B_{\max }(\mathrm{MBC})$ of ovarian follicular membrane preparation for $\left[{ }^{125} \mathrm{I}\right] \mathrm{sCT}$ was $1 \cdot 2 \mathrm{pM} / \mathrm{mg}$ protein and $K_{\mathrm{d}}$ was $48 \cdot 8 \mathrm{pM} / 1$. 

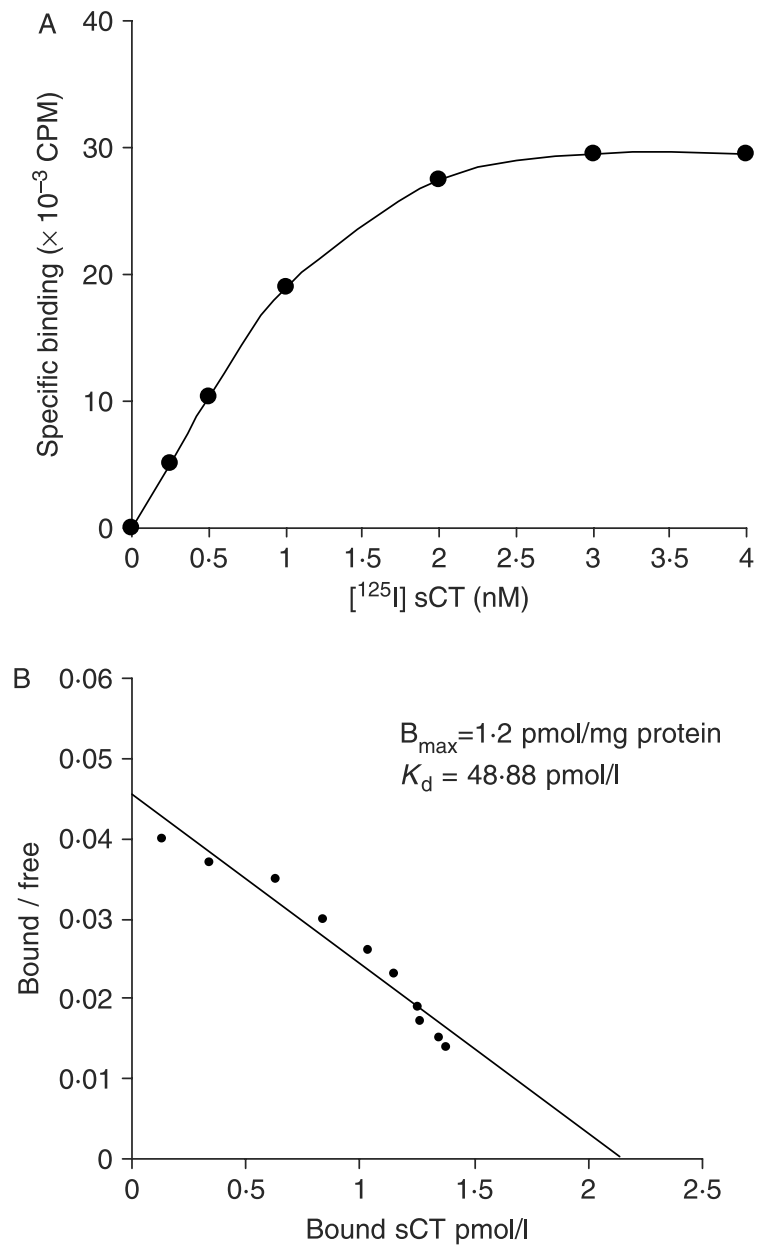

Figure 2 (A) Saturation curve of $\left[{ }^{125} \mathrm{I}\right] \mathrm{sCT}$ binding to membrane preparation of ovarian follicles of vitellogenic stage C. carpio. Specific binding was determined by subtracting the nonspecific binding from the total binding. (B) Scatchard plot of [ $\left.{ }^{125} \mathrm{I}\right] \mathrm{SCT}$ binding to fish ovarian follicular membrane preparation. (A and $B$ ) Values are \pm S.E.M. of four observations taking ovarian follicles in duplicate from four donor fish.

Effects of $s C T$ on $E_{2}$ production by the ovarian follicles in vitro

Since there was a significant increase in plasma $\mathrm{E}_{2}$ levels in vitellogenic stage fish after sCT injection, and as sCT binds with the follicular membrane preparation with high-affinity, physiological importance of sCT binding to ovarian follicles was assessed by incubating follicles with varied concentrations of sCTwithout or with hCG and steroid production was measured.

The effect of sCT ranging from 25 to $200 \mathrm{ng} / \mathrm{ml}$ incubation on $\mathrm{E}_{2}$ release by the ovarian follicles is illustrated in Fig. 3A. During a 12-h incubation, sCTat 50 ng dose released maximum quantity of $\mathrm{E}_{2}$ in the medium $(P<0 \cdot 05)$. Higher doses over $50 \mathrm{ng} /$ incubation had no additive effects (Fig. 3A). Incubation of ovarian follicles with increasing doses of hCG $(10-100 \mathrm{ng} / \mathrm{ml}$ incubation) for $12 \mathrm{~h}$ caused a significant increase of $\mathrm{E}_{2}$ release at $25 \mathrm{ng}$ dose and the highest was recorded at $50 \mathrm{ng} / \mathrm{ml}$ incubation
A

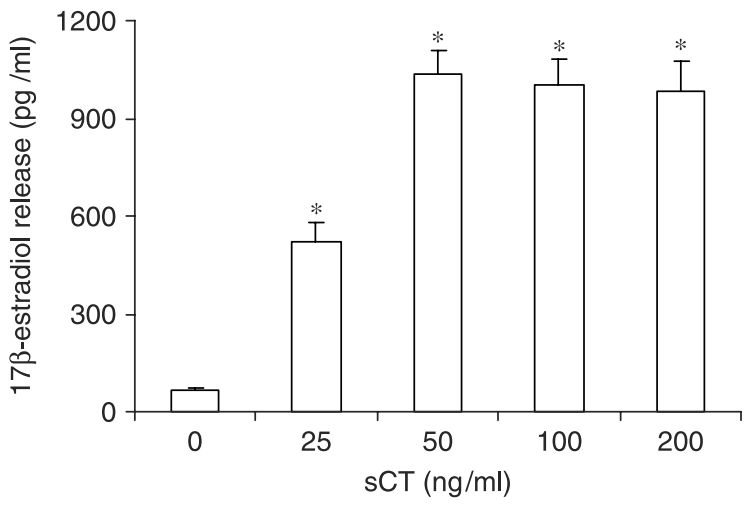

B
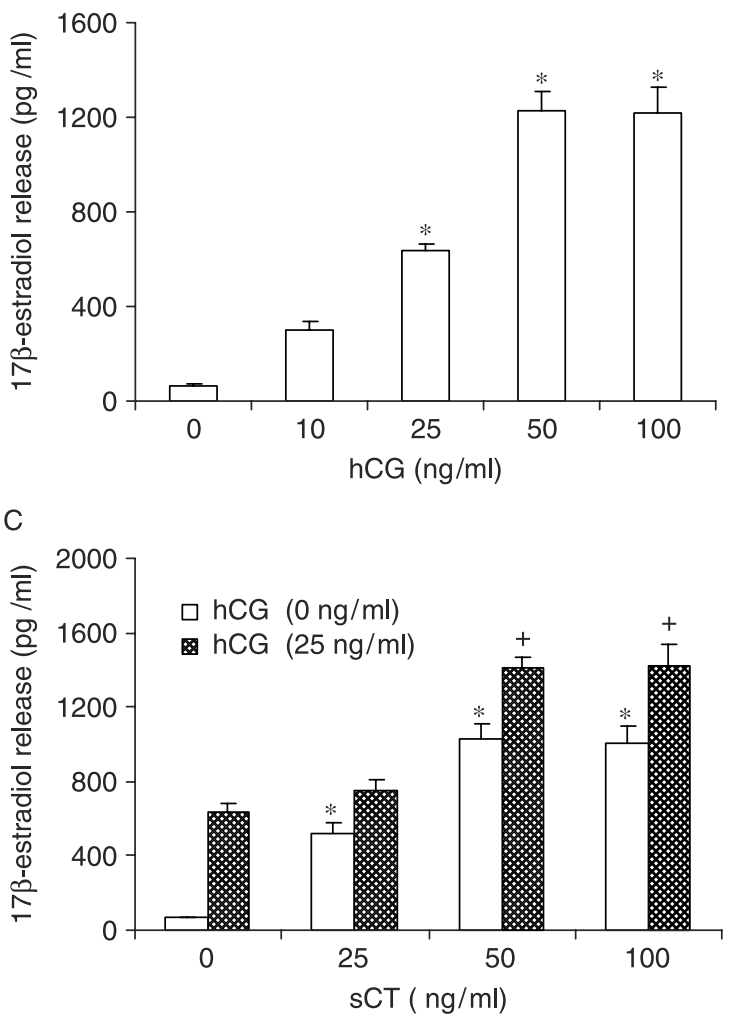

Figure 3 Dose-response effects of (A) $\mathrm{sCT}$ and (B) hCG on in vitro release of $17 \beta$-estradiol by the vitellogenic follicles of $C$. carpio. (C) Dose-response effects of sCT on basal (hollow bar) and hCGstimulated (solid bar) in vitro release of $17 \beta$-estradiol by the vitellogenic follicles of $C$. carpio. All incubations were terminated at $12 \mathrm{~h}$ after addition of test compounds. Each value represents \pm s.E.M. of five incubations taking follicles in triplicate from five donor fish ( $(A$ and $B) * P<0 \cdot 05$ versus tissues incubated without hormone $(0)$, (C) $* P<0.05$ versus $\mathrm{SCT}$ at $0 \mathrm{ng} / \mathrm{ml}$ and ${ }^{+} P<0.05$ versus hCG at $0 \mathrm{ng} / \mathrm{ml}$ ).

(Fig. 3B). Ovarian follicles were incubated with sCT $(0-100 \mathrm{ng} / \mathrm{ml})$ in the presence of hCG $(25 \mathrm{ng} / \mathrm{ml})$ for $12 \mathrm{~h}$. Figure $3 \mathrm{C}$ shows that hCG-induced release of $\mathrm{E}_{2}$ was significantly increased $(P<0 \cdot 05)$ by $\mathrm{sCT}$ ranging from 25 to $100 \mathrm{ng}$ dose/ml incubation. Ovarian follicles were incubated 
with sCTor hCG (each $50 \mathrm{ng} / \mathrm{ml}$ ) for various lengths of time up to $16 \mathrm{~h}$. It appears from Fig. 4A that after addition of hormones $\mathrm{E}_{2}$ release increased steadily from $2 \mathrm{~h}$ and the maximum was recorded at $6 \mathrm{~h}$ by sCT and $12 \mathrm{~h}$ by hCG.

\section{Effects of sCT on P450 aromatase activity}

Aromatase activity, which was estimated by in vitro conversion of labeled testosterone to labeled $\mathrm{E}_{2}$ in the ovarian follicles, were significantly stimulated by $\mathrm{sCT}$ and $\mathrm{hCG}$ at a concentration of $50 \mathrm{ng} / \mathrm{ml}(P<0 \cdot 05)$ compared with their respective control values (Fig. $4 \mathrm{~B})$.

\section{Effects of sCT and hCG on P450arom gene expression}

Total mRNAs were isolated from ovarian follicles treated without or with sCT or hCG (each $50 \mathrm{ng} / \mathrm{ml}$ ) for different
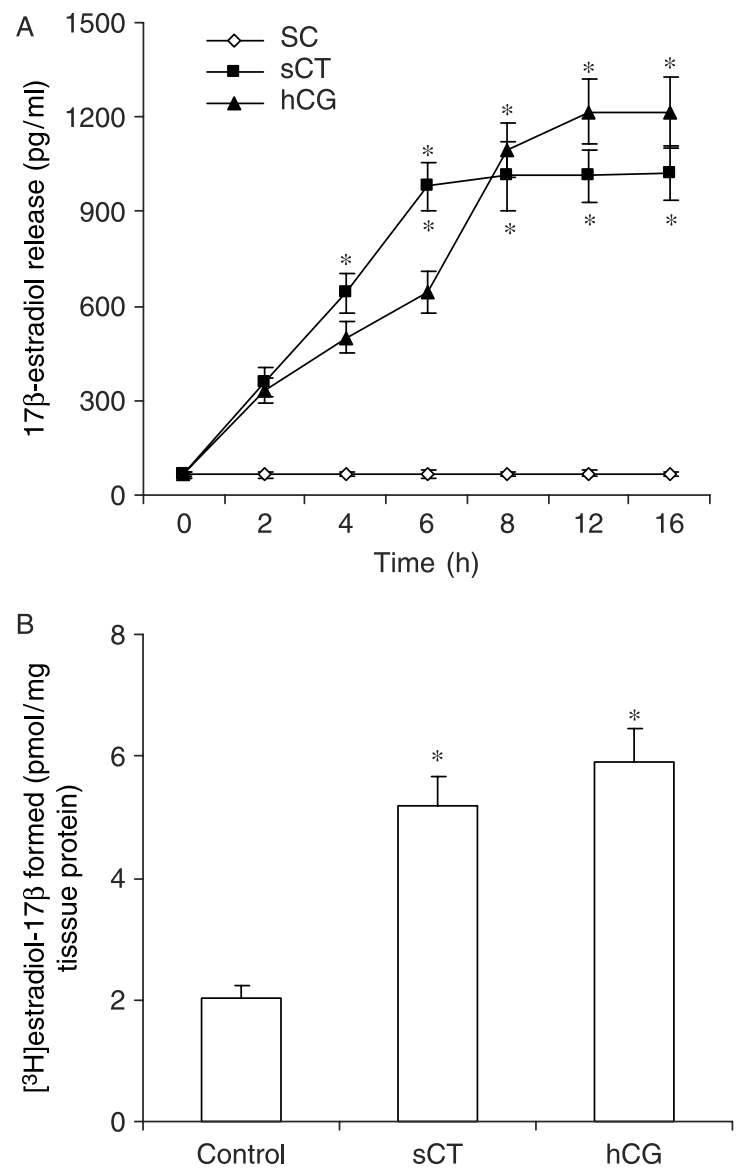

Figure 4 (A) Time-course effects of sCT and hCG (each $50 \mathrm{ng} / \mathrm{ml}$ ) on in vitro $17 \beta$-estradiol release by the vitellogenic follicles of $C$. carpio. The sCT- and hCG-stimulated conversion of $\left[{ }^{3} \mathrm{H}\right.$ testosterone to $\left[{ }^{3} \mathrm{H}\right]$ estradiol- $17 \beta$ in the ovarian follicles of $C$. carpio. Ovarian follicles were incubated in the presence of $\left[{ }^{3} \mathrm{H}\right]$ testosterone $\left(1 \times 10^{6}\right.$ c.p.m. $140 \mathrm{mmol}$ ) without or with sCT or hCG for $8 \mathrm{~h}$. Each value is the mean \pm S.E.M. of five incubations taking follicles in triplicate from five donor fish ((A) $* P<0.05$ versus saline control (SC) at respective time period, (B) $* P<0 \cdot 05$ versus saline control). time intervals and RT-PCR was performed using P450arom specific primer CYP19A. Figure 5A shows that both hCG and sCT stimulated P450arom gene expression in ovarian follicles incubated for $2 \mathrm{~h}$ and increased gradually and significantly $(P<0.05)$ from 4 to $8 \mathrm{~h}$. The expression of GAPDH was used as a loading control (Fig. 5B).

Effects of dbcAMP on sCT-stimulated $E_{2}$ release

To evaluate the role of intracellular cAMP in the regulation of sCT-induced $\mathrm{E}_{2}$ release, effects of dbcAMP (a cAMP analog to mimic increase of intracellular cAMP) on ovarian follicles were examined. Figure $6 \mathrm{~A}$ shows that dbcAMP at two increasing concentrations $(0.5$ and $1.0 \mathrm{mM})$ stimulated the release of $E_{2}$ in the medium and addition of $\mathrm{sCT}(25 \mathrm{ng} / \mathrm{ml}$ medium) potentiated the effects of dbcAMP on $\mathrm{E}_{2}$ release by the follicles.

Effects of adenylate cyclase inhibitor on sCT-stimulated $E_{2}$ release

The effects of SQ22536, a cell permeable selective adenylate cyclase inhibitor on sCT- and hCG-stimulated $\mathrm{E}_{2}$ release by the ovarian follicles, were examined. Administration of SQ22536 at increasing doses $(0.1-1.0 \mathrm{mM})$ attenuated both sCT- and hCG-stimulated $\mathrm{E}_{2}$ release in the medium in a concentration-dependent manner (Fig. 6B, $P<0 \cdot 05)$.

Effect of protein kinase $C(P K C)$ inhibitor on sCT-stimulated $E_{2}$ production

To ascertain the involvement of $\mathrm{PKC}$ in the regulation of $\mathrm{E}_{2}$ release by SCT, the effect of NPC-15437 dihydrochloride, a selective PKC inhibitor was examined. NPC-15437 at all concentrations tested $(0 \cdot 1-1 \cdot 0 \mathrm{mM})$ failed to attenuate sCTstimulated $\mathrm{E}_{2}$ release in the medium. However, PKC inhibitor attenuated hCG-stimulated $\mathrm{E}_{2}$ release in a concentration-dependent manner (Fig. $7, P<0 \cdot 05)$.

\section{Discussion}

In the present study, we found that administration of sCT to carp C. carpio during vitellogenic stage significantly stimulated spontaneous and hCG-induced secretion of $\mathrm{E}_{2}$ in vivo and in vitro. We described that ovarian follicles are equipped with $\mathrm{CT}$ receptors as evidenced from the specific binding of $\mathrm{sCT}$ to the membrane preparation. We reported that $\mathrm{SCT}$ stimulated both aromatase activity and P450arom gene expression in the ovarian follicles. Furthermore, we suggested that stimulatory action of $\mathrm{sCT}$ on ovarian $\mathrm{E}_{2}$ secretion was mediated through cAMP pathway.

CT is a hypocalcemic hormone that mineralizes bone by suppressing the activity of osteoclast in mammals 
A
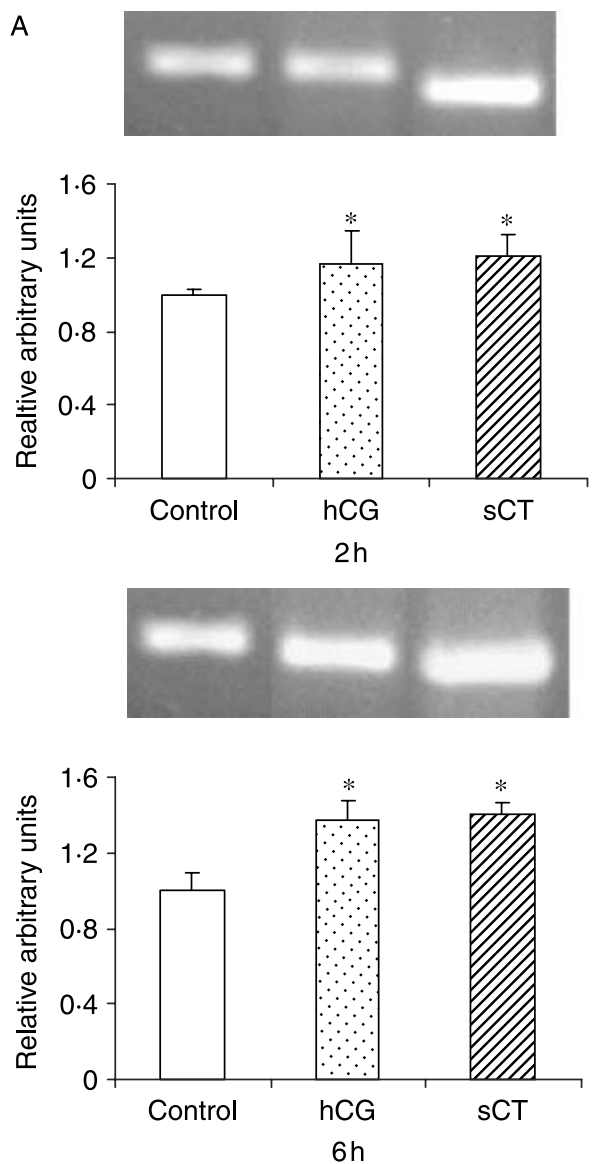
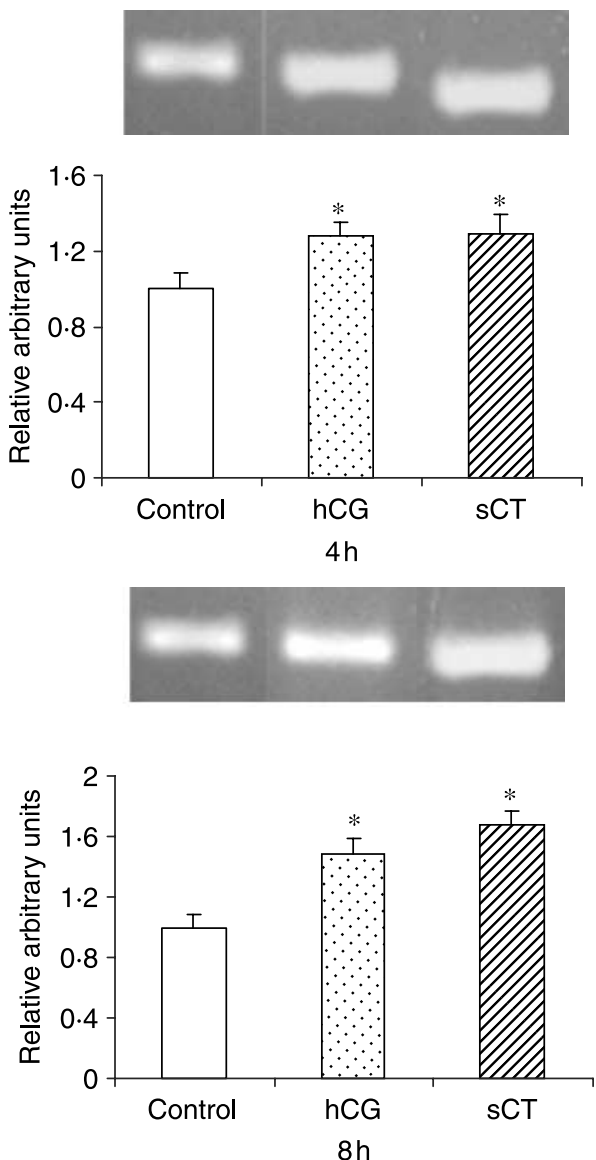

\section{B}

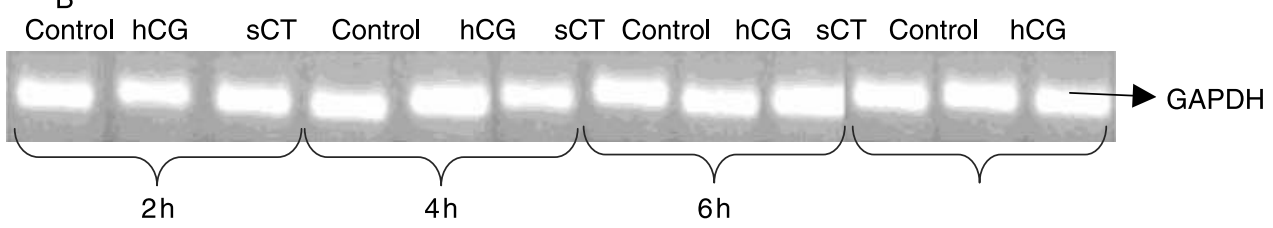

Figure 5 Effect of hCG and sCT on the expression of P450arom gene in ovarian follicles of C. carpio. Ovarian follicles were incubated for 2, 4, 6, and $8 \mathrm{~h}$ without or with sCT or hCG (each $50 \mathrm{ng} / \mathrm{ml}$ ). Total RNA was isolated from ovarian follicles and RT-PCR was performed using CYP19A gene specific primer. The amplified product was loaded in agarose gel as control, sCT, and hCG treated samples. (A) The pixel densities of the bands were quantified with ImageJ software National Institute of Health $(\mathrm{NIH})$ and have been represented in bar diagram as relative arbitrary units considering the control value as 1. (B) The expression of GAPDH was used as a loading control. The experiments were performed three times in duplicate, and the values are mean \pm s.E.M., $* P<0 \cdot 05$.

(Regnister 1993). In comparison, the role of CT in fish is poorly understood. However, several laboratories have been able to show that CT is indeed capable of altering plasma calcium levels in fish (Wendelar Bonga 1981, Wates \& Barrett 1983, Chakrabarti \& Mukherjee 1993, Srivastava et al. 1998, Mukherjee et al. 2004a,b). Nonetheless, inconclusive results are reported from time to time and there is still no consensus as to the role of CT in calcium homeostasis in fish. In contrast, evidence for a physiological role of CT during teleost sexual maturation is consistent. Histological and ultrastructural studies of ultimobranchial glands of Atlantic salmon, masu salmon, rainbow trout, zebrafish, goldfish, European eel, and Japanese eel all indicate that these glands are maximally active in sexually mature pre-ovulatory females (Oguri 1973, Peignoux-Deville et al. 1975, Yamane 1977, 1978, Yamane \& Yamada 1977). Plasma CT levels in coho salmon, Japanese eel, and rainbow trout are higher in females during the spawning season and reached a peak just before ovulation 

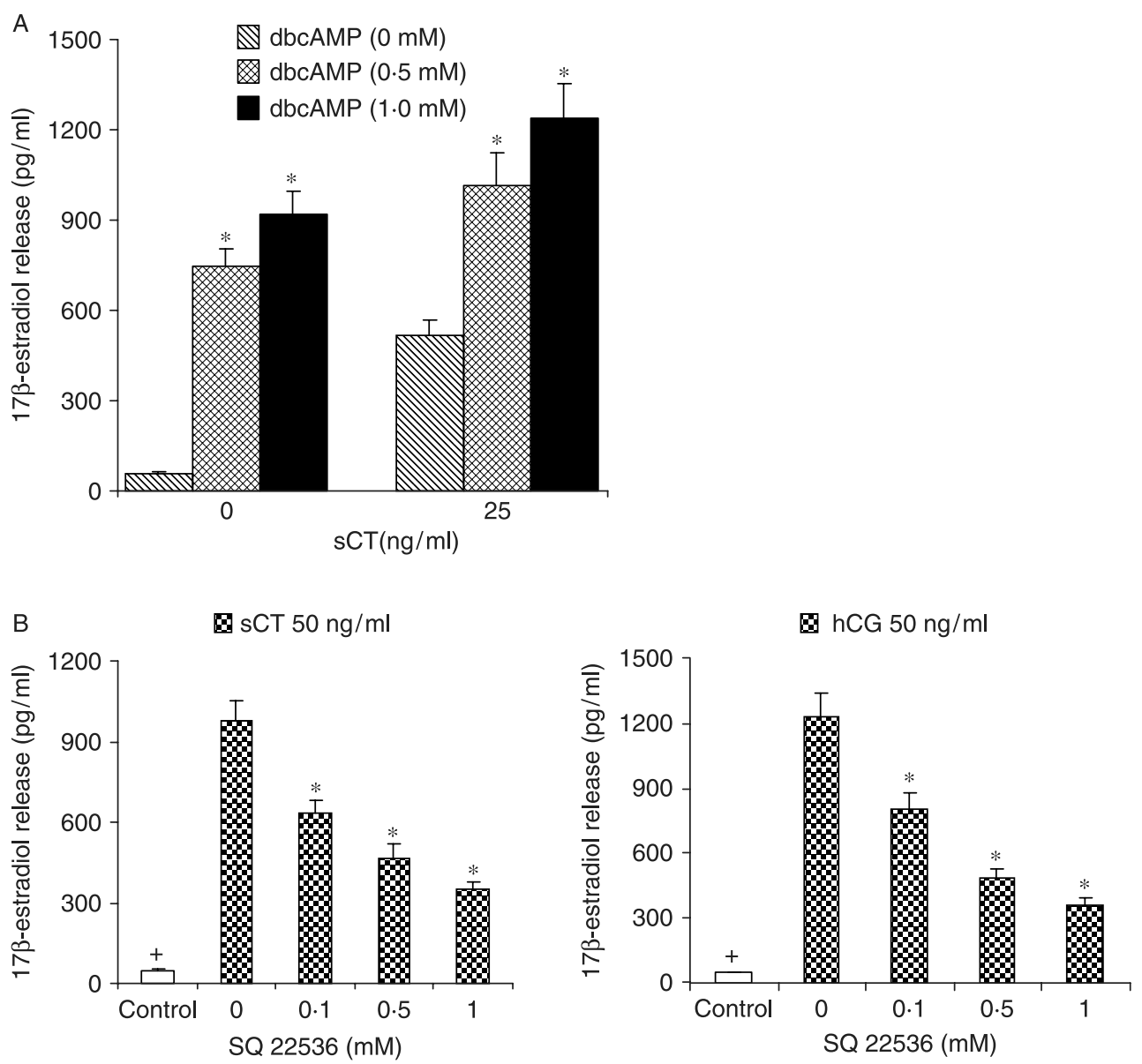

Figure 6 (A) Effects of sCTon in vitro release of $17 \beta$-estradiol by the ovarian follicles of $C$. carpio in the absence (hatched bar) or presence of $0.5 \mathrm{mM}$ (cross hatched bar) and $1.0 \mathrm{mM}$ (solid bar) dbcAMP. (B) Effects of SQ22536, a selective inhibitor of adenylate cyclase, on SCT- and hCG-stimulated in vitro $17 \beta$-estradiol release by the ovarian follicles of $C$. carpio. Ovarian follicles were incubated in the absence (control) or presence of sCT or hCG with increasing doses of SQ 22536 for $12 \mathrm{~h}$. Each value represents \pm s.E.M. of five incubations taking follicles in triplicate from five donor fish $\left({ }^{*} P<0.05\right.$ versus $\mathrm{sCT}$ corresponding control group, ${ }^{*} P<0.05$ versus hormone alone, ${ }^{+} P<0 \cdot 05$ from those shown for tissues incubated with hormone alone).

(Deftos et al. 1974, Watts et al. 1975, Yamauchi et al. 1976, 1978, Bjorsson et al. 1986, Norberg et al. 1989). The $\mathrm{E}_{2}$ increases plasma CT levels in rainbow trout (Bjornsson et al. 1986, 1989) and a direct induction of estrogen on CT secretion from ultimobranchial glands in goldfish has also been suggested (Suzuki et al. 2004). Although a possible explanation for the hyperactivity of ultimobranchial gland and the rise in plasma CT levels during peak reproductive season in female fish has been put forwarded by many workers (Bjornsson et al. 1989, Brown \& Bern 1989, Suzuki et al. 2004), none of them were able to suggest an exact relationship between $\mathrm{CT}$ and reproduction in fish.

The present study provides evidence that $\mathrm{SCT}$ is effective in increasing plasma $E_{2}$ levels in vitellogenic stage fish and stimulating both spontaneous and hCG-induced secretion of $\mathrm{E}_{2}$ by the ovarian follicles in vitro. The effect of $\mathrm{s} C T$ on steroid production both in vivo and in vitro was dose- and timedependent. For our in vivo experiment, we used fish kept in high- $\mathrm{Ca}^{2+}$ water. As shown previously, the hypocalcemic effects of $\mathrm{sCT}$ were less in fish kept in high-Ca ${ }^{2+}$ water than in normal water (Chakrabarti \& Mukherjee 1993, Mukherjee $e t$ al. $2004 a, b)$. In the present study, after sCT injection to vitellogenic fish, the level of plasma $\mathrm{Ca}^{2+}$ altered a little but the release of plasma $\mathrm{E}_{2}$ was significantly increased. We concluded that the increase of plasma $\mathrm{E}_{2}$ was independent of the $\mathrm{Ca}^{2+}$-decreased effect of sCT. Effects of $\mathrm{SCT}$ on increased plasma $\mathrm{E}_{2}$ levels might be due to its action either on high pituitary gonadotropin hormone $(\mathrm{GtH})$ release or its direct action on ovarian follicles. Intravenous infusion of CT in humans caused a calcium-independent reduction in thyrotropin and $\mathrm{LH}$ secretion in response to hypothalamic releasing hormone (Leicht et al. 1974). Inhibition of sCT on secretion of 
A

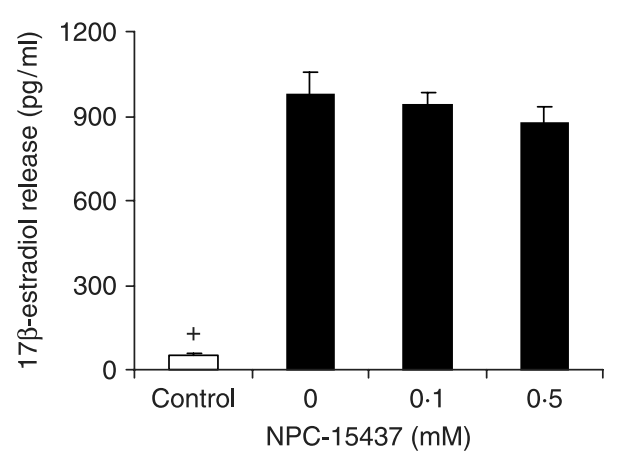

B

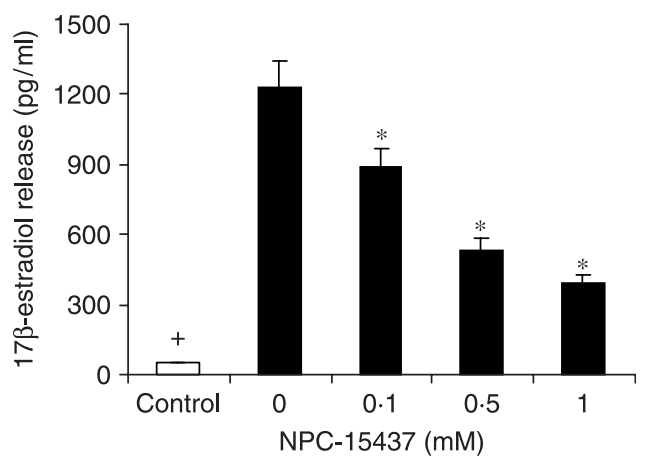

Figure 7 Effects of NPC-15437 dihydrochloride, a selective inhibitor of PKC, on (A) sCT- and (B) hCGstimulated in vitro release of $17 \beta$-estradiol by the ovarian follicles of $C$. carpio. Ovarian follicles were incubated in the absence (control) or presence of SCT or hCG with increasing doses of NPC-15437 dihydrochloride for $12 \mathrm{~h}$. Each point represents \pm s.E.M. of five incubations taking follicles in triplicate from five donor fish $\left({ }^{*} P<0.05\right.$ versus hormone alone, ${ }^{+} P<0.05$ from those shown for tissues incubated with hormone alone).

progesterone and GnRH-stimulated pituitary LH has also been reported (Tsai et al. 1999). Moreover, receptors of CT-designated $\mathrm{C} 1 \mathrm{a}$ and $\mathrm{C} 1 \mathrm{~b}$ receptors have been identified in rat brains (Sexton \& Hilton 1992, Albrandt et al. 1993). All these studies indicate a physiological role for $\mathrm{CT}$ at the pituitary and ovarian levels in mammals. However, no such information is yet available in fish. Indeed, in our present study, we did not observe pituitary LH release after sCT injection of fish. Therefore, the possibility of a CT-regulated GtH release by the pituitary cannot be ruled out. As observed in our present study, $25 \mathrm{ng}$ sCT peptides are effective in stimulating spontaneous and hCG-induced in vitro $\mathrm{E}_{2}$ release by the ovarian follicles. Therefore, the reason for the sCT-induced rise in plasma $\mathrm{E}_{2}$ levels is that $\mathrm{S} C \mathrm{~T}$ stimulated $\mathrm{E}_{2}$ production by acting directly on ovarian follicular cells in the fish.

A result of the present study shows that $\mathrm{sCT}$ can bind specifically to carp ovarian membrane preparation. This indicates the presence of receptor molecules in the carp ovarian follicles which recognize sCT. Binding of CT with membrane preparation was found to be saturable with high affinity $\left(B_{\max }, 1.2 \mathrm{pmol} / \mathrm{mg}\right.$ protein, $\left.K_{\mathrm{d}} 48.8 \mathrm{pmol} / \mathrm{l}\right)$. Available information on the presence of CT-binding sites and sCT-induced inhibition of progesterone secretion in rat granulosa cells indicate a physiological role of CT at ovarian levels in mammals (Tsai et al. 1999). Our finding is the first report on the presence of $\mathrm{SCT}$ receptor in the fish ovary apart from its presence in gills. Therefore, the presence of functional receptors for $\mathrm{CT}$ in the ovarian membrane preparation of vitellogenic follicles and $\mathrm{sCT}$-induced in vitro production of $\mathrm{E}_{2}$ by the ovarian follicles clearly indicate a functional link between binding and specific biological response.

In the present study, significant augmentation of aromatase activity, both in hCG- and sCT-treated ovarian follicles, is supported by a high rate of conversion of aromatizable androgen (testosterone to $\mathrm{E}_{2}$ ) and enhanced the synthesis and release of $E_{2}$ under stimulation of both the hormones. We also showed for the first time in teleost that $\mathrm{SCT}$ stimulated P450arom gene expression in the ovarian follicles. It has been well documented that the fish ovarian follicles possess an aromatase enzyme participating in the conversion of aromatizable androgen to $E_{2}$, while P450arom mRNA levels, are increased in association with the increase of enzyme activity under the stimulation of hCG (Gen et al. 2001, Kagawa et al. 2003).

It has been well established that in the fish ovary, gonadotropin stimulates steroid production involving both PKA and PKC pathways (Nagahama 1987, Srivastava \& Van der Kraak 1994). In our experiment, we found that in addition to the lone effect of $\mathrm{sCT}$ on $\mathrm{E}_{2}$ production, stimulatory effects of hCG on $\mathrm{E}_{2}$ production in vitro were potentiated in the presence of sCT. Results indicate that administration of dbcAMP stimulated sCT-induced $\mathrm{E}_{2}$ production and cell permeable selective inhibitor of adenylate cyclase, SQ 22356 attenuated both hCG- and sCT-induced $\mathrm{E}_{2}$ production. The specific PKC inhibitor NPC-15437 dihydrochloride on the other hand had no inhibitory effects on sCT-stimulated $\mathrm{E}_{2}$ release. Therefore, we suggest that the signal for $\mathrm{sCT}$-stimulated $\mathrm{E}_{2}$ release might be transduced through the cAMP pathway and interaction between sCT and hCG on the signal transduction in the fish ovary is still open to question. Increased production of cAMP caused by CT that has been demonstrated in perfused rat bone, osteoblast-like cell line, osteoclast, atria and aortic smooth muscle (Kubota et al. 1985, Sugimoto et al. 1986, Nicholson et al. 1987, Wang \& Fiscus 1989, Iida-Klein et al. 1992), and in the rat testicular and anterior pituitary gland (Wang et al. 1994) substantiate 
the action of CT through the cAMP pathway in the fish ovarian follicles.

Our present finding on the stimulatory role of sCT on basal and hCG-induced $\mathrm{E}_{2}$ production by fish ovarian follicles is completely opposite to the observed action of CT in the mammalian ovary and testes in the regulation of steroid production. Our unpublished data with ovarian follicles of perch Anabas testudineus also showed the same stimulatory action of $\mathrm{sCT}$ on $\mathrm{E}_{2}$ production. Although the action of $\mathrm{CT}$ is well characterized in mammals, its action in fish, particularly with regard to calcium regulation is still controversial. Therefore, the observed stimulatory effect of CT on fish ovarian steroidogenesis, in contrast to mammals, is not unusual. It is most likely that CT has evolved a distinct function in different lineage, which probably relates to its aquatic life and this needs further studies on higher group of vertebrates. In addition, the exact physiological relevance of the stimulation of $\mathrm{E}_{2}$ production by $\mathrm{SCT}$ in the fish ovary, when $\mathrm{GtH}$-stimulated $\mathrm{E}_{2}$ production is normally operative, is not clear. Researchers have become increasingly aware that the traditional concept of the action of $\mathrm{GtH}$ in the regulation of ovarian growth, maturation, and steroidogenesis may no longer be tenable. Localization of several neuropeptides in the nerve that innervate the ovary, neuropeptide $\mathrm{Y}$, substance $\mathrm{P}$, vasoactive intestinal polypeptide (VIP) and somatostatin in the ovary of mammals have already been reported (Ojeda et al. 1985, Ahmed et al. 1986, McDonald et al. 1987). Although the function of most of these peptides in the ovary remain unknown, stimulatory effects of VIP on estrogen and progesterone release from cultured granulosa cells have been reported. Reports are also available that the stimulatory action of VIP appears to be exerted, at least in part, through a direct stimulatory action of neuropeptides on the synthesis of the cholesterol-side chain cleavage enzyme (Trzecizk et al. 1986, 1987). Recently, Clark et al. (2002) reported for the expression of the CT gene in the ovary of a teleost, Fugu rubripes and suggested that CT may act as a potential neuropeptide. Considering all these, it would appear that CT in fish may take some role, at least in part, to support the action of $\mathrm{GtH}$ on the ovary during vitellogenic growth by acting independently or synergistically with GtH. This assumption supports the high plasma CT levels in fish during this phase of gonadal growth (Deftos et al. 1974, Yamauchi et al. 1978, Bjorsson et al. 1986).

In summary, the present findings suggest that $\mathrm{sCT}$ stimulates $E_{2}$ production in vitellogenic ovarian follicles of carp C. carpio by acting directly on the ovary, without altering plasma calcium levels. Membranes of ovarian follicles are equipped with functional CT receptors with high affinity. sCT could stimulate both basal and hCG-stimulated $\mathrm{E}_{2}$ release. The stimulatory effect of $\mathrm{sCT}$ on $\mathrm{E}_{2}$ production is associated with an increase of $\mathrm{P} 450$ aromatase activity and $\mathrm{P} 450$ arom gene expression in ovarian follicles. The signal transduction of the stimulatory effects of sCT is mediated through cAMP pathway.

\section{Acknowledgements}

The authors are thankful to Dr Arun Bandopadhyay, Molecular Endocrinology Laboratory, Indian Institute of Chemical Biology, Kolkata, India for providing laboratory facilities and kindly donating SQ 22536 and NPC- 15437 dihydrochloride. This work is supported by grants to the Kalyani University from Council of Scientific and Industrial Research (CSIR), New Delhi (37 (0997)/98- EMR-II) and from the University research grant (IF-1/99/DP- 917) to Dola Mukherjee. There is no conflict of interest that would prejudice the impartiality of the research.

\section{References}

Ahmed CE, Dees WL \& Ojeda SR 1986 The immature rat ovary is innervated by vasoactive intestinal peptide (VIP)-containing fibres and responds to VIP with steroid production. Endocrinology 118 1682-1689.

Albrandt K, Mull E, Brady EMG, Herich J, Moore CX \& Beaumont K 1993 Molecular cloning of two receptors from rat brain with high affinity for salmon calcitonin. FEBS Letters 325 225-232.

Azria M 1989 Endogenous calcitonin. In The Calcitonins: Physiology and Pharmacology, ch 2, pp 22-23. Basel, Switzerland: Karger.

Birnbaumer L \& Swartz T 1982 Membrane receptors: criteria and selected methods of study. In Laboratory Methods Manual for Hormone Action and Molecular Endocrinology, 2, pp 3-1-3-29. Eds WT Schrader \& BW O' Malley. Houston, USA: Houston Biological Association, Inc.

Bjorsson BTH, Haux C, Forlin L \& Deftos LJ 1986 The involvement of calcitonin in the reproductive physiology of the rainbow trout. Journal of Endocrinology 108 17-22.

Bjorsson BTH, Haux C, Bern HA \& Deftos LJ 1989 17ß-Estradiol increases plasma calcitonin levels in salmonid fish. Endocrinology 125 1754-1760.

Brown CL \& Bern HA 1989 Thyroid hormones in early development, with special reference to teleost fishes. In Development, Maturation and Senescence of neuroendocrine Systems: A Comparative Approach, pp 289-306.

Eds M Schreibman \& C Scanes. New York: Academic Press.

Chakrabarti P \& Mukherjee D 1993 Studies on the hypocalcemic actions of salmon calcitonin and ultimobranchial gland extracts in the freshwater teleost Cyprinus carpio. General and Comparative Endocrinology 90 267-273.

Chan WK \& Tan CH 1986 FSH-induced aromatase activity in porcine granulosa cells: non-competitive inhibition by non-aromatizable androgens. Journal of Endocrinology 108 335-341.

Chan DKO, Chester-Jones I \& Smith RN 1968 The effects of mammalian calcitonin on the plasma calcium and inorganic phosphate in the European eel (Anguilla anguilla L). General and Comparative Endocrinology 11 243-254.

Chausmer AB, Stevens MD \& Severn C 1982 Autoradiographic evidence for a calcitonin receptor on testicular leydig cells. Science 16 735-736.

Chomczynski P \& Sacchi N 1987 Single step method of RNA isolation by acid guanidium thiocyanate-phenol-chloroform extraction. Analytical Biochemistry 162 156-159.

Clark MS, Bendell L, Power DM, Warner S, Elgar G \& Ingleton PM 2002 Calcitonin: characterization and expression in a teleost fish, Fugu rubripes. Journal of Molecular Endocrinology 28 111-123.

Cooper CW, Peng TC, Obie JF \& Garner SC 1980 Calcitonin-like immunoreactivity in rat and human pituitary glands: histochemical, in vitro and in vivo. Endocrinology 107 98-107.

Copp DH, Cameron EC, Cheney BA, Davidson AGF \& Henze KG 1962 A hormone from parathyroid that lowers the calcium level of the blood. Endocrinology 70 638-649.

Copp DH, Cockcroft DW \& Kueh Y 1967 Calcitonin from ultimobranchial glands of dogfish and chickens. Science 158 924-925. 
Cressent M, Elie C, Taboulet J, Moukhtar MS \& Milhaud G 1983 Calcium regulating hormone during the estrous cycle of the rat. Proceedings of the Society for Experimental Biology and Medicine 172 158-162.

Deftos LJ, Watts EG, Copp DH \& Potts JT, Jr 1974 Radioimmunoassay for salmon calcitonin. Endocrinology 94 155-160.

Fischer A, Tobler PH, Kaufmann M, Born W, Henke H, Cooper PE, Sager SM \& Martin JB 1981 Calcitonin: regional distribution of the hormone and its binding sites in the human brain and pituitary lobes of rats. PNAS $\mathbf{7 8}$ 7801-7805.

Foster GV, Macintyre I \& Pearse AGE 1964 Calcitonin production and the mitochondria-rich cells of dog thyroid. Nature 203 1029-1030.

Fukada S, Tanaka M, Matsuyama M, Kobayashi D \& Nagahama Y 1996 Isolation, characterization and expression of cDNA encoding the medaka (Oryzias latipes) ovarian follicle cytochrome P-450 aromatase. Molecular Reproduction and Development 45 285-290.

Gen K, Okuzawa K, Kumakura N, Yamaguchi Y \& Kagawa H 2001 Correlation between messenger RNA expression of cytochrome P450 aromatase and its enzyme activity during oocyte development in the red seabream (Pagrus major). Biology of Reproduction 65 1186-1194.

George SE, Bungay PJ \& Naylor LH 1997 Functional coupling of endogenous serotonin (5-HT1B) and calcitonin (C1a) receptors in CHO cells to a cyclic AMP- responsive luciferase reporter gene. Journal of Neurochemistry 69 $1278-1285$.

Iida-Klein A, Yee CD, Brandli DW, Mirikitani EJM \& Hahn TJ 1992 Effects of calcitonin on $3^{\prime}, 5^{\prime}$ monophosphate and calcium second messenger generation osteoblast function in UMR 106-06 osteoblast-like cells. Endocrinology 130 381-388.

Kagawa H, Gen K, Okuzawa K \& Tanaka H 2003 Effects of luteinizing hormone and follicle-stimulating hormone and insulin-like growth factor-I on aromatase activity and P450 aromatase gene expression in the ovarian follicles of red seabream, Pagrus major, Biology of Reproduction 68 1562-1568.

Kubota M, Moseley JM, Butera L, Dusting GJ, MacDonald PS \& Martin TJ 1985 Calcitonin gene related peptide stimulates cyclic AMP formation in rat aortic smooth muscle cells. Biochemical and Biophysical Research Communications 132 88-94.

Leicht E, Biro G \& Weinges KF 1974 Inhibition of releasing-hormoneinduced secretion of TSH and LH by calcitonin. Hormone and Metabolic Research 7 410-414.

Lowry OH, Rosebrough NJ, Farr AL \& Randall RJ 1951 Protein measurement with the folin phenol reagent. Journal of Biological Chemistry 193 265-275.

Maurer R, Marbach P \& Mousson R 1983 Salmon calcitonin binding sites in rat pituitary. Brain Research 261 346-348.

McDonald JK, Dees WL, Ahmed CE, Noe BD \& Ojeda SR 1987 Biochemical and immunocytochemical characterization of neuropeptide $\mathrm{Y}$ in the immature rat ovary. Endocrinology 120 1703-1710.

Milhaud G, Rankin JC, Bolis L \& Benson AA 1977 Calcitonin: its hormonal action on the gill. PNAS 74 4693-4696.

Mukherjee D, Chakraborti P \& Debnath S 2001 Steroid production in vitellogenic and postvitellogenic ovarian follicles of common carp Cyprinus carpio: modulation by calcium ionophore. Proceedings of the Zoological Society $521-13$

Mukherjee D, Sen U, Bhattacharyya SP \& Mukherjee D 2004a Inhibition of whole body $\mathrm{Ca}^{2+}$ uptake in fresh water teleosts, Channa punctatus and Cyprinus carpio in response to salmon calcitonin. Journal of Experimental Zoology 301A 882-890.

Mukherjee D, Sen U, Bhattacharyya SP \& Mukherjee D $2004 b$ The effects of calcitonin on plasma calcium levels and bone metabolism in the fresh water teleost Channa punctatus, Comparative Biochemistry and Physiology, Part A 138 417-426.

Mukherjee D, Mukherjee D, Sen U, Paul S \& Bhattacharyya SP 2006 In vitro effects of insulin-like growth factors and insulin on oocyte maturation and maturation-inducing steroid production in ovarian follicles of common carp, Cyprinus carpio, Comparative Biochemistry and Physiology, Part A 144 63-77.

Nagahama Y 1987 Gonadotropin action on gametogenesis and steroidogenesis in teleost gonads. Zoological Science 4 209-222.
Nicholson GC, Mosley JM, Yatess AJP \& Martin TJ 1987 Control of cyclic adenosine $3^{\prime}, 5^{\prime}$ monophosphate production activation and homologous desensitization of adenylate cyclase. Endocrinology 120 1902-1908.

Norberg B, Bjornsson BTH, Brown CL, Wichardt U-P, Deftos LJ \& Haux C 1989 Changes in plasma vitellogenin, sex steroids, calcitonin, thyroid hormones and calcium related to sexual maturation in female brown trout (Salmo trutta). General and Comparative Endocrinology 75 316-326.

Oguri M 1973 Seasonal histological changes in the ultomobranchial gland of the gold fish. Bulletin of the Japanese Society of Scientific Fisheries 30 851-858.

Ojeda SR, Cosca ME, Katz KH \& Hersh LB 1985 Evidence for the existence of substance $\mathrm{P}$ in the prepubertal rat ovary I biochemical and physiological studies. Biology of Reproduction 33 286-295.

Peignoux- Deville JE, Lallier F, Martelly- Bagot E \& Millet C 1975 Responses of the ultimobranchial body in eels (Anguilla anguilla L.) maintained in sea water and experimentally matured to injections of synthetic salmon calcitonin. Cell and Tissue Research 164 73-83.

Regnister JY 1993 Calcitonin for prevention and treatment of osteoporosis. American Journal of Medicine 95 (Suppl 5A) 44S-47S.

Roy SS, Mukherjee M, Bhattacharya S, Mandal CN, Ravi Kumar L, Dasgupta S, Bandyopadhyay I \& Wakabayashi K 2003 A new cell secreting insulin. Endocrinology 144 1585-1593.

Sen U, Mukherjee D, Bhattacharyya SP \& Mukherjee D 2002 Seasonal changes in plasma steroid levels in Indian major carp (Labeo rohita): influence of homologous pituitary extract on steroid production and development of oocyte maturational competence. General and Comparative Endocrinology 128 123-134.

Sexton PM \& Hilton JM 1992 Biologically active salmon calcitonin-like peptide is present in rat brain. Brain Research 596 279-284.

Srivastava RK \& Van Der Kraak G 1994 Effects of activators of different intracellular signaling pathways on steroid production by goldfish vitellogenic ovarian follicles. General and Comparative Endocrinology 93 181-191.

Srivastava AK, Srivastava SK, Sasayama Y \& Suzuki N 1998 Salmon calcitonin induced hypocalcemia and hypophostaemia in an elasmobranch Dasyatis akajei, General and Comparative Endocrinology 109 8-12.

Sugimoto T, Fukase M, Tsutsumi M, Tsunenari T \& Fujita T 1986 Altered parathyroid hormone- or calcitonin - stimulated adenosine $3^{\prime}, 5^{\prime}$ monophosphate release by isolated perfused bone from glucocorticoidtreated rats. Calcified Tissue International 38 163-169.

Suzuki N, Yamamoto K, Sasayama Y, Suzuki T, Kurokawa T, Kambegawa A, Srivastav AK, Hayashi S \& Kikuyama S 2004 Possible direct induction by estrogen of calcitonin secretion from ultimobranchial cells in the goldfish. General and Comparative Endocrinology 138 121-127.

Trzecizk WH, Ahmed CE, Simpson ER \& Ojeda SR 1986 Vasoactive intestinal peptiode induces the synthesis of the cholesterol side-chain cleavage enzyme complex in cultured rat ovarian granulosa cells. PNAS 83 $7490-7494$.

Trzecizk WH, Waterman MR, Simpson ER \& Ojeda SR 1987 Vasoactive intestinal peptide regulates cholesterol side-hain cleavage cytochrome $\mathrm{P}-450$ (P-450scc) gene expression in granulosa cells from immature rat ovaries. Molecular Endocrinology 1 500-504.

Tsai SC, Lu CC, Chen JJ, Chiao YC, Wang SW, Hwang JJ \& Wang PS 1999 Inhibition of salmon calcitonin on secretion of progesterone and GnRHstimulated pituitary luteinzing hormone. American Journal of Physiology, Endocrinology and Metabolism 277 49-55.

Wagner GF, Jaworski EM \& Radman DP 1997 Slmon calcitonin inhibits whole body $\mathrm{Ca}^{2+}$ uptake in young rainbow trout. Journal of Endocrinology 155 459-465.

Wang X \& Fiscus RR 1989 Calcitonin gene related peptide increases cAMP tension, and rate in rat atria. American Journal of Physiology. Regulatory, Integrative and Comparative Physiology 256 R 421-R 428.

Wang PS, Tsai SC, Hwang GS, Wang SW, Lu CC, Chen JJ, Liu SR, Lee $\mathrm{Y}$, Chien EJ, Chien $\mathrm{CH}$ et al. 1994 Calcitonin inhibits testosterone and luteinizing hormone secretion through a mechanism involving an increase in cAMP production in rats. Journal of Bone and Mineral Research 9 1583-1590. 
Wates NAM \& Barret AL 1983 Depression of sodium, chloride and calcium ions in the plasma of goldfish (Carassius auratus) and in immature freshwater and seawater-adapted eels (Anguilla anguilla L.) after acute administration of salmon calcitonin. Journal of Endocrinology 98 257-261.

Watts EG, Copp DH \& Deftos LJ 1975 Changes in plasma calcitonin and calcium during the migration of salmon. Endocrinology 96 214-218.

Wendelaar Bonga SE 1981 Effect of synthetic salmon calcitonin on proteinbound and free plasma calcium in the teleost, Gasterosteus aculeatus, General and Comparative Endocrinology 43 123-126.

Wendelaar Bonga SE \& Pang PKT 1991 Control of calcium regulating hormones in the vertebrates: parathyroid hormone, calcitonin, prolactin, and stanniocalcin. International Review of Cytology 128 139-213.

Yamane S 1977 Sexual differences in histology and of the ultimobranchial gland of mature Japaneese eel (Anguilla japonica). Zoological Magazine 86 261-263.

Yamane S 1978 Histology and fine structure of the ultomobranchial gland in the zebra fish, Brachydanio rerio. Bulletin of the Faculty of Fisheries 29 213-221.
Yamane S \& Yamada J 1977 Histological changes in the ultomobranchial gland through the life history of the Masu salmon. Bulletin of the Japanese Society of Scientific Fisheries 43 375-386.

Yamauchi H, Matsuo M, Yamauchi K, Takano K, Takahashi H \& Orimo H 1976 Studies on ultimobranchial calcitonin (4)- serum calcitonin levels in eel. Igaku no Ayumi 99 499-500.

Yamauchi H, Orimo H, Yamauchi K \& Takahashi H 1978 Increased calcitonin level during ovarian development in the eel, Anguilla japonica, General and Comparative Endocrinology 36 526-529.

Received in final form 17 November 2007

Accepted 23 November 2007

Made available online as an Accepted Preprint 23 November 2007 